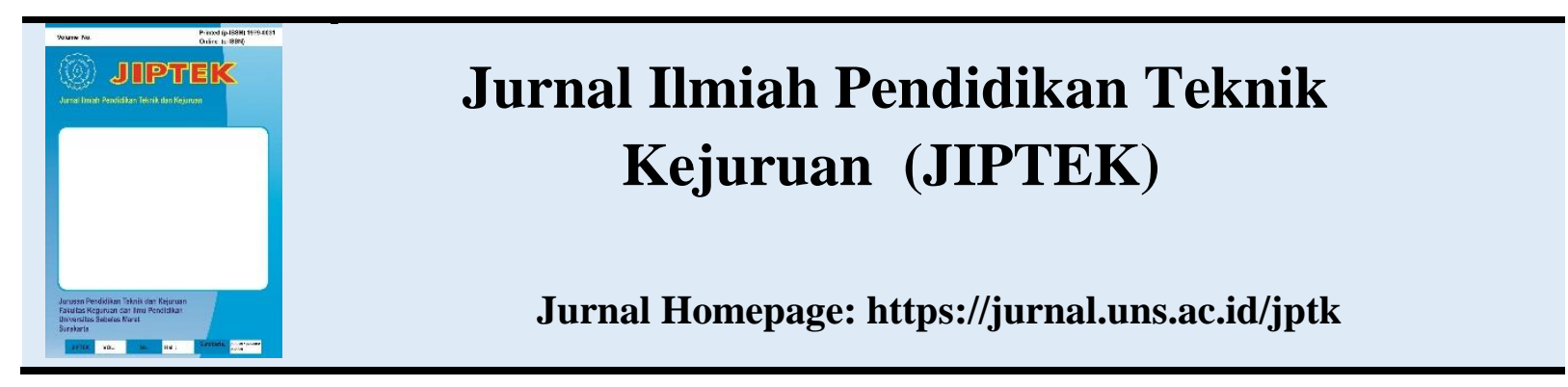

\title{
PENGARUH PENGGUNAAN SMARTPHONE DAN INTENSITAS BERMAIN GAME TERHADAP HASIL BELAJAR KOGNITIF SISWA KELAS X SMK NEGERI 1 SUKOHARJO
}

\author{
Dwi Niken Sari ${ }^{1}$, Agus Efendi ${ }^{2}$, Basori ${ }^{3}$ \\ 1,2,3Program Studi Pendidikan Teknik Informatika dan Komputer, Universitas Sebelas \\ Maret \\ Email: dwi.nikensari@gmail.com
}

\begin{abstract}
ABSTRAK
Penelitian ini bertujuan untuk mengetahui ada tidaknya (1) pengaruh penggunaan smartphone terhadap hasil belajar kognitif siswa kelas X TKJ SMK Negeri 1 Sukoharjo; (2) pengaruh intensitas bermain game terhadap hasil belajar kognitif siswa kelas X TKJ SMK Negeri 1 Sukoharjo; (3) Adakah interaksi penggunaan smartphone dan intensitas bermain game terhadap hasil belajar kognitif siswa kelas X TKJ SMK Negeri 1 Sukoharjo; dan (4) penggunaan smartphone ataukah intensitas bermain game yang mempunyai sumbangan lebih besar terhadap hasil belajar kognitif siswa kelas X TKJ SMK Negeri 1 Sukoharjo. Penelitian ini menggunakan metode ex-post facto. Analisis data menggunakan uji regresi sederhana dan uji regresi berganda kemudian dilanjutkan dengan uji t-parsial, uji $\mathrm{F}$ dan menghitung sumbangan relatif serta sumbangan efektif. Populasi dalam penelitian ini adalah siswa kelas X TKJ SMK Negeri 1 Sukoharjo. Sampel yang terpilih adalah 61 siswa dari kelas X TKJ dengan teknik pengambilan sampel random sampling. Hasil penelitian adalah sebagai berikut ini. Pertama, ada pengaruh positif dan signifikan penggunaan smartphone terhadap hasil belajar kognitif siswa kelas $\mathrm{X}$ TKJ SMK Negeri 1 Sukoharjo (t hitung=2,214>t tabel=2,001). Kedua, ada pengaruh negatif dan signifikan antara intensitas bermain game terhadap hasil belajar kognitif siswa kelas X TKJ SMK Negeri 1 Sukoharjo (t hitung=2,841> t tabel=2,001). Ketiga, ada interaksi signifikan antara penggunaan smartphone dan intensitas bermain game terhadap hasil belajar kognitif siswa kelas X TKJ SMK Negeri 1 Sukoharjo ( $\mathrm{F}$ hitung=7,790>F tabel=3,156). Keempat, intensitas bermain game memiliki pengaruh yang lebih tinggi terhadap hasil belajar siswa dibandingkan variabel penggunaan smartphone.
\end{abstract}

Kata Kunci : penggunaan smartphone, intensitas bermain game, hasil belajar, kognitif

\begin{abstract}
This research aims to determine (1) the effect of the smartphones usage on cognitive achievement of tenth grade TKJ class in SMK Negeri 1 Sukoharjo; (2) the effect of playing games intensity on cognitive achievement of tenth grade TKJ class in SMK Negeri 1 Sukoharjo; (3) the interaction between smartphones usage and playing games games on cognitive achievement of tenth grade TKJ class in SMK Negeri 1 Sukoharjo; and (4) smartphones usage or playing games intensity that have the greater contribution on cognitive achievement of students of tenth grade TKJ class in SMK Negeri 1 Sukoharjo. This research use ex-post facto method. Data were analyzed with simple regression test and multiple regression test. The population of this research was the student of tenth grade TKJ class in SMK Negeri 1 Sukoharjo. 61 students from both Tenth grade TKJ class were selected as the sample through random sampling technique. The results show that (1) there were positive and significant effect of smartphones
\end{abstract}


usage on cognitive achievement of tenth grade TKJ class in SMK Negeri 1 Sukoharjo $(t=2.214>t$ table=2.001); (2) there were negative and significant effect of playing games intensity on cognitive achievement of tenth grade TKJ class in SMK Negeri 1 Sukoharjo $(t=2.841>t$ table $=2.001)$; (3) there were significant interaction between smartphones usage and playing games intensity on cognitive achievement of tenth grade TKJ class in SMK Negeri 1 Sukoharjo with F=7.790>F table=3.156;(4) playing games intensity have a higher impact on achievement of students compared to the smartphones usage.

Keywords: Smartphones usage, playing games intensity, achievement, cognitive

\section{PENDAHULUAN}

\section{Latar Belakang Masalah}

Kehidupan manusia sekarang tidak bisa terlepas dari teknologi. Sebuah teknologi pada hakikatnya diciptakan untuk membuat hidup manusia semakin menjadi nyaman dan mudah. Teknologi ada di setiap aspek kehidupan manusia, dimulai dari teknologi dalam pertanian, pendidikan, komunikasi dan dalam aspek kehidupan lainnya. Contoh berkembangnya teknologi dalam perihal komunikasi dan informatika adalah ditemukannya telepon genggam dan komputer. Seiring ditemukannya telepon genggam diikuti dengan dikembangkannya smartphone dan game.

Siswa-siswi jurusan TKJ SMK Negeri 1 Sukoharjo pun tidak terlepas dari kemajuan teknologi komunikasi dan informasi. Pembelajaran di jurusan TKJ sering memanfaatkan proyektor dan laptop/komputer, terkadang siswa-siswi TKJ SMK Negeri 1

Sukoharjo menggunakan smartphone yang dimiliki untuk membantu dalam pembelajaran atau sekedar mencari materi pelajaran. Siswasiswi SMK Negeri 1 Sukoharjo sudah banyak yang memiliki smartphone. Bisa terlihat pada saat istirahat, pulang sekolah dan saat jam kosong beberapa siswa mengeluarkan smartphone untuk mendengarkan musik, membuka media sosial, dan ada pula yang bermain game di laptop mereka. Hal ini menyebabkan beberapa guru menjadi khawatir dengan nilai yang akan didapat oleh para siswa tersebut. Sebenarnya SMK Negeri 1 Sukoharjo melarang siswa untuk membawa telepon genggam maupun smartphone, tetapi untuk laptop masih diperbolehkan karena nantinya akan digunakan untuk pembelajaran.

Semakin maraknya kasus kecanduan smartphone dan bermain game mendorong beberapa ahli untuk meneliti dampak dari kedua hal tersebut. Menurut Paul Wilson, hardcore gamer dapat meluangkan 16-20 jam per hari untuk bermain game. Peneliti lain telah mendokumentasikan hubungan negatif yang serupa antara jumlah waktu bermain game dan prestasi anak kuliah (Anderson \& Dill, 2000: 772-790). Dalam penelitian tersebut ditemukan bahwa banyaknya waktu yang dihabiskan dengan bermain game dapat berpengaruh terhadap perilaku remaja yaitu remaja menjadi malas. 
Walaupun sudah ada beberapa ahli yang melakukan penelitian tentang dampak smartphone dan bermain game, akan tetapi masih belum bisa diketahui kepastian dampak yang diperoleh oleh siswa, apakah berdampak positif atau berdampak negatif terhadap hasil belajar kognitif siswa. Aspek kognitif dipandang sebagai aspek terpenting dari perkembangan siswa yang berkaitan langsung dengan proses pembelajaran, dan sangat menentukan keberhasilan siswa di sekolah. Aspek kognitif dengan otak sebagai perangkat kerasnya merupakan pengendali dari aspekaspek lainnya seperti yang telah dikemukakan oleh Muhibbin Syah (2003: 48).

Berdasarkan pemikiran tersebut di atas, maka penulis terdorong untuk melakukan penelitian dengan judul "Pengaruh Penggunaan Smartphone dan Intensitas Bermain Game terhadap Hasil Belajar Kognitif Siswa Kelas X SMK Negeri 1 Sukoharjo".

\section{Tujuan Penelitian}

Tujuan penelitian ini untuk mengetahui:

1. Mengetahui ada tidaknya pengaruh penggunaan smartphone terhadap hasil belajar kognitif siswa kelas X TKJ SMK Negeri 1 Sukoharjo.

2. Mengetahui ada tidaknya pengaruh intensitas bermain game terhadap hasil belajar kognitif siswa kelas X TKJ SMK Negeri 1 Sukoharjo.

3. Mengetahui ada tidaknya interaksi penggunaan smartphone dan intensitas bermain game terhadap hasil belajar kognitif siswa kelas X TKJ SMK Negeri 1 Sukoharjo.

4. Mengetahui di antara penggunaan smartphone dan intensitas bermain game yang mempunyai sumbangan lebih besar terhadap hasil belajar kognitif siswa kelas X TKJ SMK Negeri 1 Sukoharjo.

\section{Kajian Pustaka}

Dalam Kamus Besar Bahasa Indonesia, penggunaan diartikan sebagai proses, cara perbuatan memakai sesuatu, pemakaian (KBBI, 2003: 852). Menurut Williams \& Sawyer (2011, 385), smartphone adalah telepon selular dengan mikroprosesor, memori, layar dan modem bawaan. Smartphone merupakan ponsel multimedia yang bekerja layaknya komputer. Penggunaan smartphone dapat diartikan sebagai segala kegiatan/aktifitas memakai fitur-fitur yang ada pada telepon pintar (smartphone) yang bekerja layaknya komputer baik itu untuk memudahkan komunikasi, mencari informasi dan alasan lainnya.

Intensitas berasal dari bahasa Inggris yaitu intensity yang berarti kemampuan, kekuatan, gigih atau kehebatan (Echols dan Shadily, 1993: 326). Menurut M. Hafi (1996: 297), intensitas diartikan sebagai kuatnya tingkah laku atau pengalaman, atau sikap yang dipertahankan. Kata game berasal bahasa inggris yang mempunyai arti permainan. Menurut Nilwan (1995) game merupakan permainan komputer yang dibuat dengan teknik dan metode animasi. Apabila digabungkan antara pengertian dari intensitas dan game dapat disimpulkan bahwa intensitas bermain game 
adalah besarnya usaha seseorang dalam kegiatan bermain aplikasi permainan dalam bentuk elektronik yang dapat menarik perhatian.

Hasil belajar seringkali digunakan sebagai ukuran untuk mengetahui seberapa jauh seseorang menguasai bahan yang sudah diajarkan, hasil belajar merupakan pencapaian tujuan pendidikan pada siswa yang mengikuti proses belajar mengajar. Menurut Sudjana (1995: 3), hasil belajar adalah perubahan tingkah laku, tingkah laku sebagai hasil belajar yang dimaksud mencakup bidang kognitif, afektif dan psikomotorik. Hasil belajar bisa diartikan juga sebagai perubahan yang mengakibatkan manusia berubah dalam sikap dan tingkah lakunya. Ada juga yang memahami hasil belajar atau achievement itu adalah bentuk realisasi atau pemakaran dari kecakapan kecakapan potensial atau kapasitas yang dimiliki seseorang.

\section{METODE}

\section{Jenis Penelitian}

Jenis penelitian yang digunakan penelitian ini adalah penelitian kuantitatif karena nantinya data-data yang diperoleh berhubungan dengan angka-angka. Metode penelitian yang digunakan penulis dalam penelitian ini dengan melihat pertimbanganyang ada adalah dengan metode penelitian ex-post facto. Metode ex-post facto dirasa sesuai karena dalam penelitian ini rangkaian variabel-variabel telah terjadi dan juga penulis tidak melakukan kontrol terhadap variabel-variabel yang terjadi, variabel dilihat sebagaimana adanya.

\section{Populasi dan Sampel}

Populasi dalam penelitian ini adalah seluruh siswa kelas $X$ TKJ SMK Negeri 1 Sukoharjo tahun pelajaran 2015/2016. Kelas X TKJ A terdiri dari 36 siswa dan kelas X TKJ B juga terdiri dari 36 siswa, berarti untuk populasi dari penelitian ini berjumlah 72 siswa. Sampel penelitian dipilih secara acak (random sampling). Untuk menentukan besarnya sampel menurut teknik Slovin menurut Sugiyono (2012: 87). Sehingga didapatkan jumlah sampel yang akan digunakan adalah 61 sampel.

\section{Teknik Pengumpulan Data}

Teknik yang digunakan dalam pengumpulan data dalam penelitian ini adalah dengan teknik kuesioner/angket dan dokumentasi. Teknik kuesioner/angket pada penelitian ini digunakan untuk memperoleh data penggunaan smartphone dan intensitas bermain game siswa. Terdapat dua angket yaitu angket penggunaan smartphone dan angket intensitas bermain game. Teknik dokumentasi digunakan untuk memperoleh data hasil belajar kognitif siswa. Hasil belajar kognitif siswa yang akan digunakan adalah nilai ulangan tengah semester.

\section{Teknik Analisis Data}

Teknik analisis data yang digunakan dalam penelitian ini adalah analisis regresi tunggal dan ganda. Sebelum dilakukan analisis data dilakukan uji prasyarat analisis yang meliputi uji normalitas, uji linieritas, uji heteroskedastisitas, uji multikolinieritas, dan uji homogenitas. 


\section{HASIL PENELITIAN DAN}

\section{PEMBAHASAN}

Data penggunaan smartphone menunjukkan skor tertinggi 70 dari skor tertinggi yang mungkin dicapai sebesar 80 dan skor terendah yang dicapai sebesar 38 dari skor terendah yang mungkin dicapai sebesar 20 . Mean sebesar 52,32 dan skor total sebesar 3192.

Data intensitas bermain game menunjukkan skor tertinggi 56 dari skor tertinggi yang mungkin dicapai sebesar 68 dan skor terendah yang dicapai sebesar 33 dari skor terendah yang mungkin dicapai sebesar 17 . Mean sebesar 44,45 dan skor total sebesar 2712.

Data hasil belajar kognitif menunjukkan nilai tertinggi adalah 10,00 dan nilai terendah yang dicapai sebesar 5,20. Mean dari nilai hasil belajar kognitif siswa tersebut adalah sebesar 8,25 dan jumlah total nilai siswa sebesar 503.45.

\section{Hasil Uji Hipotesis}

Hipotesis pertama adalah "Terdapat pengaruh antara penggunaan smartphone terhadap hasil belajar kognitif siswa kelas $\mathrm{X}$ TKJ SMK Negeri 1 Sukoharjo". Guna menganalisis dan menguji hipotesis pertama digunakan teknik analisis regresi linier sederhana.

Tabel 1. Hasil Analisis Regresi Linier Sederhana X1-Y

\begin{tabular}{cccc}
\hline Model & Nilai B & $\begin{array}{c}\text { Nilai t } \\
\text { hitung }\end{array}$ & $\begin{array}{c}\text { Nilai } \\
\text { Sig. }\end{array}$ \\
\hline Konstanta & 5,971 & 5,736 & 0,000 \\
Penggunaan & 0,044 & 2,214 & 0,031 \\
Smartphone & & & \\
\hline
\end{tabular}

Dari tabel di atas diperoleh persamaan regresi sebagai berikut: $\mathrm{Y}=5,971+0,044 \mathrm{X} 1$. Adapun interprestasi dari persamaan linier sederhana tersebut adalah (1) nilai $\mathrm{a}=5,971$, berarti bahwa tanpa adanya penggunaan smartphone, maka besar hasil belajar kognitif adalah 5,971 ; (2) $b=0,044$, berarti bahwa setiap kenaikan nilai penggunaan smartphone sebesar 1, maka hasil belajar kognitif akan bertambah sebesar 0,044. Hasil t hitung $>\mathrm{t}$ tabel, yaitu 2,214>2,001, berarti penggunaan smartphone mempunyai pengaruh signifikan terhadap hasil belajar siswa. Begitu pula apabila dilihat dari nilai sig., nilai sig. variabel penggunaan smartphone sebesar 0,031 yang lebih kecil dari 0,05 , berarti variabel penggunaan smartphone memiliki pengaruh signifikan terhadap hasil belajar yang dicapai siswa. Dengan demikian hipotesis pertama diterima.

Hipotesis kedua adalah "Terdapat pengaruh antara intensitas bermain game terhadap hasil belajar kognitif siswa kelas $\mathrm{X}$

TKJ SMK Negeri 1 Sukoharjo”. Guna menganalisis dan menguji hipotesis kedua digunakan teknik analisis regresi linier sederhana.

Tabel 2. Hasil Perhitungan Analisis Regresi Linier Sederhana X2-Y

\begin{tabular}{cccc}
\hline Model & Nilai B & $\begin{array}{c}\text { Nilai t } \\
\text { hitung }\end{array}$ & $\begin{array}{c}\text { Nilai } \\
\text { Sig. }\end{array}$ \\
\hline (Constant) & 12,054 & 8,959 & 0,000 \\
$\begin{array}{c}\text { Intensitas } \\
\text { Bermain Game }\end{array}$ & $-0,085$ & $-2,841$ & 0,006 \\
\hline
\end{tabular}


Dari tabel di atas diperoleh persamaan regresi sebagai berikut : $\mathrm{Y}=12,054-0,085 \mathrm{X} 2$. Adapun interprestasi dari persamaan linier sederhana tersebut adalah (1) nilai a $=12,054$, berarti bahwa tanpa adanya intensitas bermain game, maka besar hasil belajar kognitif adalah 12,054 ; (2) $b=-0,085$, berarti bahwa setiap kenaikan nilai intensitas bermain game sebesar 1, maka hasil belajar kognitif akan berkurang sebesar 0,085 . Hasil $t$ hitung $>t$ tabel, yaitu $2,841>2,001$, berarti intensitas bermain game mempunyai pengaruh signifikan terhadap hasil belajar siswa. Begitu pula apabila dilihat dari nilai sig., nilai sig. variabel intensitas bermain game sebesar 0,006 yang lebih kecil dari 0,05, berarti variabel intensitas bermain gamememiliki pengaruh signifikan terhadap hasil belajar yang dicapai siswa. Dengan demikian hipotesis kedua diterima.

Hipotesis ketiga adalah "Terdapat interaksi antara penggunaan smartphone dan intensitas bermain game terhadap hasil belajar kognitif siswa kelas X TKJ SMK Negeri 1 Sukoharjo". Guna menganalisis dan menguji hipotesis ketiga digunakan teknik analisis regresi linier ganda.

Tabel 3. Hasil Perhitungan Analisis Regresi Linier Berganda-Coeficient

\begin{tabular}{cccc}
\hline Model & Nilai B & $\begin{array}{c}\text { Nilai t } \\
\text { hitung }\end{array}$ & $\begin{array}{c}\text { Nilai } \\
\text { Sig. }\end{array}$ \\
\hline (Constant) & 9,792 & 6,306 & 0,000 \\
Penggunaan & 0,048 & 2,593 & 0,012 \\
$\begin{array}{c}\text { Smartphone } \\
\text { Intensitas } \\
\text { Bermain } \\
\text { Game }\end{array}$ & $-0,091$ & $-3,152$ & 0,003 \\
\hline
\end{tabular}

Tabel 4. Hasil Perhitungan Analisis Regresi Linier Berganda-Anova

\begin{tabular}{cccc}
\hline $\begin{array}{c}\text { Pasangan } \\
\text { Variabel }\end{array}$ & df & $\begin{array}{c}\text { Nilai F } \\
\text { hitung }\end{array}$ & $\begin{array}{c}\text { Nilai } \\
\text { Sig. }\end{array}$ \\
\hline $\mathrm{X} 1 \mathrm{X} 2-\mathrm{Y}$ & 2 & 7,790 & 0,001 \\
\hline
\end{tabular}

Berdasarkan tabel di atas diperoleh persamaan regresi linear ganda sebagai berikut : $\quad \mathrm{Y}=$ 9,792+0,048X1-0,091X2. Adapun interpretasi dari persamaan regresi linear ganda tersebut adalah: (1) $\mathrm{a}=9,792$, berarti bahwa tanpa adanya penggunaan smartphone dan intensitas bermain game, maka nilai hasil belajar kognitif adalah 9,792; (2) b1 =0,048, berarti bahwa setiap kenaikan penggunaan smartphone sebesar 1, maka hasil belajar kognitif akan bertambah sebesar 0,048. Dengan asumsi tidak ada penambahan ataupun pengurangan intensitas bermain game; (3) b2=0,091, berarti bahwa setiap kenaikan nilai intensitas bermain game sebesar 1, maka hasil belajar kognitif akan berkurang sebesar -0,091 satuan. Dengan asumsi tidak ada penambahan ataupun pengurangan penggunaan smartphone. Hasil F hitung $>\mathrm{F}$ tabel, yaitu 7,790>3,156, berarti adanya interaksi/ pengaruh secara bersama-sama antara penggunaan smartphone dan intensitas bermain game terhadap hasil belajar kognitif siswa. Dengan demikian hipotesis ketiga diterima.

Hipotesis keempat adalah "Intensitas bermain game mempunyai sumbangan yang lebih besar terhadap hasil belajar kognitif siswa kelas X TKJ SMK Negeri 1 Sukoharjo dibandingkan dengan penggunaan smartphone". Guna menganalisis dan menguji 
hipotesis keempat dilakukan perhitungan nilai sumbangan relatif dan efektif. Berdasarkan analisis data diperoleh nilai koefisien determinasi (R2) sebesar 0,212. Arti dari koefisien ini adalah bahwa pengaruh yang diberikan oleh kombinasi penggunaan smartphone dan intensitas bermain game terhadap hasil belajar kognitif adalah sebesar $21,2 \%$, sedangkan sisanya $78,8 \%$ dipengaruhi oleh variabel lain. Hasil perhitungan diketahui bahwa variabel penggunaan smartphone memberikan sumbangan relatif sebesar $39,73 \%$ dan sumbangan efektif $8,42 \%$. Variabel intensitas bermain game memberikan sumbangan relatif sebesar $60,26 \%$ dan sumbangan efektif sebesar 12,77\%. Dengan membandingkan nilai sumbangan relatif dan efektif nampak bahwa variabel intensitas bermain game memiliki pengaruh yang lebih tinggi terhadap hasil belajar kognitif siswa dibandingkan variabel penggunaan smartphone. Dengan demikian hipotesis keempat diterima.

\section{PEMBAHASAN}

Hasil penelitian menunjukkan bahwa sebagian besar pada siswa kelas X TKJ SMK Negeri 1 Sukoharjo memiliki tingkat penggunaan smartphone kategori sedang yaitu 49,18\% dari 61 siswa. Dari hasil analisis regresi sederhana antara penggunaan smartphone dan haisl belajar siswa diperoleh persamaan : UTS = $5,971+0,044$ SP. Konstanta sebesar 5,971 artinya jika penggunaan smartphone bernilai 0 , maka hasil belajar yang didapat oleh siswa adalah 5,971. Berdasarkan persamaan tersebut diketahui koefisien arah regresi dari variabel penggunaan smartphone adalah sebesar 0,044 (positif), yang berarti apabila penggunaan smartphone mengalami kenaikan 1 skor maka hasil belajar siswa akan mengalami kenaikan sebesar 0,044. Uji keberartian koefisien arah regresi linier sederhana untuk variabel penggunaan smartphone diperoleh $\mathrm{t}$ hitung $>\mathrm{t}$ tabel $=2,214>2,001$, sehingga dapat disimpulkan bahwa variabel penggunaan smartphone berpengaruh secara signifikan terhadap hasil belajar kognitif siswa. Hasil pengujian ini menunjukkan bahwa semakin besarnya penggunaan smartphone maka semakin tinggi hasil belajar yang dicapai. Penggunaan smartphone yang dimaksudkan adalah penggunaan dengan arah positif yaitu menggunakan smartphone untuk hal-hal baik, misalkan untuk mencari materi pelajaran, membantu mencari jawaban pekerjaan rumah dan tugas, serta untuk menghubungi orangorang dekat, bukan menggunakan smartphone yang dimiliki hanya untuk bersenang-senang, bekerja sama saat ulangan ataupun tindakan tidak baik lainnya. Dengan demikian, pengujian ini menerima hipotesis pertama yaitu terdapatnya pengaruh signifikan antara penggunaan smartphone terhadap hasil belajar kognitif siswa kelas X TKJ SMK Negeri 1 Sukoharjo.

Hasil penelitian menunjukkan bahwa sebagian besar pada siswa kelas X TKJ SMK Negeri 1 Sukoharjo memiliki tingkat intensitas bermain game kategori tinggi yaitu $68,85 \%$ dari 61 siswa. Dari hasil analisis regresi sederhana antara intensitas bermain game dan hasil belajar siswa diperoleh persamaan : UTS $=12,054$ 0,085 GK. Konstanta sebesar 12,054 artinya 
jika intensitas bermain game bernilai 0, maka hasil belajar yang didapat oleh siswa adalah 12,054. Berdasarkan persamaan tersebut diketahui koefisien arah regresi dari variabel intensitas bermain game adalah sebesar -0,085, yang berarti apabila intensitas bermain game mengalami kenaikan 1 skor maka hasil belajar siswa akan mengalami penurunan sebesar 0,085. Uji keberartian koefisien arah regresi linier sederhana untuk variabel intensitas bermain game diperoleh $\mathrm{t}$ hitung $>\mathrm{t}$ tabel $=$ 2,841>2,001, sehingga dapat disimpulkan bahwa intensitas bermain game berpengaruh secara signifikan terhadap hasil belajar kognitif siswa. Begitu pula apabila dilihat dari nilai sig, nilai sig variabel intensitas bermain game sebesar 0,006 yang lebih kecil dari 0,05 juga menunjukkan bahwa intensitas bermain game memiliki pengaruh signifikan terhadap hasil belajar yang dicapai siswa. Hal ini disebabkan karena sifat addictive dari game yang dapat menyebabkan anak menjadi lebih senang berjam-jam bermain dengan game sehingga siswa tidak fokus dalam belajar, melupakan tugas atau pekerjaan rumah dan cenderung lebih tertarik dengan bermain game daripada belajar. Hasil pengujian ini menunjukkan bahwa semakin besarnya intensitas bermain game maka semakin rendah hasil belajar yang dicapai. Dengan demikian, pengujian ini menerima hipotesis kedua yaitu terdapatnya pengaruh signifikan antara intensitas bermain game terhadap hasil belajar kognitif siswa kelas $\mathrm{X}$ TKJ SMK Negeri 1 Sukoharjo.

Berdasarkan hasil analisis regresi
berganda antara interaksi dari variabel

penggunaan smartphone dan intensitas bermain game terhadap hasil belajar kognitif siswa didapatkan persamaan regresi : UTS $=9,792+$ 0,048SP - 0,091GK. Konstanta sebesar 9,792 artinya jika penggunaan smartphone dan intensitas bermain game bernilai 0 , maka hasil belajar yang didapat oleh siswa adalah 9,792. Dari persamaan regresi berganda tersebut juga dapat diketahui beberapa hal di bawah ini :

1. Apabila skor penggunaan smartphone naik dan intensitas bermain game naik maka nilai hasil belajar kognitif akan turun,

2. Apabila skor penggunaan smartphone turun dan intensitas bermain game turun maka nilai hasil belajar kognitif akan naik,

3. Apabila skor penggunaan smartphone naik dan intensitas bermain game turun maka nilai hasil belajar kognitif akan naik,

4. Apabila skor penggunaan smartphone turun dan intensitas bermain game naik maka nilai hasil belajar kognitif akan turun.

Pada pengujian nilai $\mathrm{F}$ diperoleh nilai $\mathrm{F}$ hitung $>\mathrm{F}$ tabel $(7,790>3,156)$, yang menandakan penggunaan smartphone dan intensitas bermain game berpengaruh secara bersama-sama terhadap hasil belajar yang dicapai oleh siswa. Berdasarkan hasil tersebut dapat dikatakan bahwa interaksi penggunaan smartphone dan intensitas bermain game berpengaruh signifikan terhadap hasil belajar kognitif siswa. Penggunaan smartphone dan intensitas bermain game secara bersama-sama mempengaruhi hasil belajar siswa namun pengaruh tersebut berbanding terbalik antara satu dan yang lain. Penggunaan smartphone mempunyai koefisien regresi sebesar 0,048 
(positif), yang menandakan kenaikan penggunaan smartphone akan menyebabkan kenaikan hasil belajar siswa, penggunaan yang dimaksudkan adalah penggunaan tinggi yang positif yaitu menggunakan smartphone untuk hal-hal baik, misalkan untuk mencari materi pelajaran, membantu mencari jawaban pekerjaan rumah dan tugas, serta untuk menghubungi orang-orang dekat, bukan menggunakan smartphone yang dimiliki hanya untuk bersenang-senang, bekerja sama saat ulangan ataupun tindakan tidak baik lainnya.

Sedangkan intensitas bermain game mempunyai koefisien regresi sebesar -0,091 (negatif), yang menandakan kenaikan intensitas menyebabkan penurunan hasil belajar siswa. Hal ini disebabkan karena sifat addictive dari game yang dapat menyebabkan anak menjadi lebih senang berjam-jam bermain dengan game sehingga siswa tidak fokus dalam belajar, melupakan tugas atau pekerjaan rumah dan cenderung lebih tertarik dengan bermain game daripada belajar. Dengan demikian, pengujian ini menerima hipotesis ketiga yaitu terdapatnya interaksi signifikan antara penggunaan smartphone dan intensitas bermain game terhadap hasil belajar kognitif siswa kelas $\mathrm{X}$ TKJ SMK Negeri 1 Sukoharjo.

Dari hasil perhitungan sumbangan relatif dan sumbangan efektif masing-masing variabel bebas didapatkan hasil penggunaan smartphone mempunyai $\mathrm{SR}=39,73 \%$ dan $\mathrm{SE}=8,42 \%$ sedangkan intensitas bermain game mempunyai $\mathrm{SR}=60,26 \%$ dan $\mathrm{SE}=12,77 \%$. Dengan membandingkan nilai sumbangan relatif dan efektif nampak bahwa variabel intensitas bermain game memiliki pengaruh yang lebih tinggi terhadap hasil belajar siswa dibandingkan variabel penggunaan smartphone. Hal ini mungkin disebabkan oleh sifat addictive dan menyenangkan dari bermain game, sehingga dapat menyebabkan anak lebih sangat ketergantungan bermain game dan sangat tertarik untuk memainkan suatu game.

\section{SIMPULAN DAN SARAN}

\section{Simpulan}

Berdasarkan pengujian hipotesis dan pembahasan yang telah dilakukan maka dapat disimpulkan sebagai berikut :

1. Terdapat pengaruh positif dan signifikan antara penggunaan smartphone terhadap hasil kognitif belajar siswa kelas X TKJ SMK Negeri 1 Sukoharjo.

2. Terdapat pengaruh negatif dan signifikan antara intensitas bermain game terhadap hasil belajar kognitif siswa kelas X TKJ SMK Negeri 1 Sukoharjo.

3. Terdapat interaksi antara penggunaan smartphone dan intensitas bermain game terhadap hasil belajar kognitif siswa kelas $X$ TKJ SMK Negeri 1 Sukoharjo. Penggunaan smartphone berpengaruh positif(searah) terhadap hasil belajar siswa sedangkan intensitas bermain game lebih berpengaruh negatif(tidak searah).

4. Intensitas bermain game memiliki pengaruh yang lebih tinggi terhadap hasil belajar siswa dibandingkan variabel penggunaan smartphone. 


\section{Saran}

Berdasarkan hasil penelitian ini, maka diajukan saran sebagai berikut :

1. Bagi Siswa

Diharapkan para siswa mampu memanfaatkannya dengan sebaikbaiknya, jangan sampai kemajuan teknologi tersebut menimbulkan dampak negatif yang akhirnya menyebabkan menurunnya hasil belajar.

2. Bagi Pendidik dan Pihak Sekolah Diharapkan para guru dan pihak sekolah agar lebih memperhatikan para siswa yang membawa smartphone dan laptop dalam lingkungan sekolah terlebih lagi di dalam kelas jangan sampai siswa menyalahgunakan fungsi alat-alat tersebut ke fungsi negatif seperti menggunakan smartphone dan bermain game saat pembelajaran berlangsung.

3. Bagi Orang Tua Siswa Diharapkan orang tua senantiasa tidak terlalu memanjakan anaknya dengan membelikan smartphone, laptop atau teknologi-teknologi canggih lain yang berlebihan.

4. Bagi Penelitian Selanjutnya

Perlu diperhatikan juga dalam pengambilan data hendaknya peneliti memilih waktu yang tepat untuk mengambil data. Penelitian selanjutnya dapat menggunakan variabel-variabel yang lainnya untuk menghubungkan dengan hasil pembelajaran, sebaiknya peneliti yang lain juga diharapkan untuk menyempurnakan alat ukur untuk hasil yang lebih baik.

\section{DAFTAR PUSTAKA}

Alwi, H. (2003). Kamus Besar Bahasa Indonesia. Jakarta : Balai Pustaka.

Anderson, C.A, \& Dill, K.E. (2000). Video Games and Aggressive Thoughts, Feelings, and Behavior in the Laboratory and Life. Journal of Personality and Social Psychology. Diperoleh 10 April 2016, dari https://www.unimuenster.de/imperi

$\mathrm{a} / \mathrm{md} /$ content/psyifp/aeechterhoff/winter semester2011/seminarthemenfelderders ozialpsychologie/12_anderson_dill_vide ogames-aggressivethoug hts_jpsp2000.pdf

Brusco, J.M. (2010). Using Smartphone Application in Perioperative Practice. AORN Journal. Diperoleh 10 April 2016, dari http://dx.doi.org

/10.1016/j.ao rn.2010.09.001.

Echols, John M., \& Shadily, H. (1993). Kamus Inggris Indonesia. Jakarta :

PT. Gramedia.

M. Hafi, A. (1996). Kamus Psychology. Surabaya : Usaha Nasional.

Nilwan, A. (1995). Pemograman Animasi dan Game Profesional. Jakarta : Elex Media Komputindo.

Sudjana, N. (1995). Penilaian Hasil Proses Belajar Mengajar. Bandung : Remaja Rosdakarya.

Sugiyono. (2012). Statistika untuk Penelitian. Bandung: Alfabeta.

Williams, B.K. \& Sawyer, S.C. (2011). Using Information Technology : A Practical

Introduction to Computers \& Communications (9th edition). New York : McGraw-Hill. 